For all criteria studied the differences were all the larger as the fertilization level of the herd was low and in particular when changing from 0 to 1 return.

In the case where sows can easily be reintegrated into the batches ( 1 or 3 week-intervals between batches) mating of sows returning 1-2 times to heats is more advantageous for the breeder.

\title{
The objectives of pig breeding in France
}

\author{
L. OLLIVIER \\ I.N.R.A., Station de Génétique quantitative et appliquée, \\ Centre de Recherches zootechniques, \\ F 78350 Jouy-ent-Josas
}

Several possibilities exist for defining the overall objective of pig production, for choosing the elementary objectives and for combining them. The goals which have been defined ten years ago are re-examined on account of changes in the economic conditions of pig production in France, and particularly the use of the European system of carcass grading since 1972. Prediction equations for carcass value (using measurements obtained in the standardized Parisian jointing system) have been derived from a sample of 15648 female pigs jointed and graded in the progeny-lesting station from 1972 to 1978 . These equations are similar to the prediction equations for muscle percentage obtained by Hamelin (see Naveau and PommereT, 1979, Techni-Porc, 2 (4), 7-12). Furthermore, though the present grading system practically ignores meat quality, is inclusion among the selection objectives is considered. A modification of the grading sysiem in order to take meat quality into account appears to be desirable.

\section{Genetic parameters of Large White and French Landrace progeny testing female pigs over the 1970-1978 period}

\author{
L. OLLIVIER, A. DERRIEN et M. MOLENAT \\ I.N.R.A., Station de Génétique quantitative et appliquée, \\ Centre de Recherches zootechniques, \\ F 78350 Jouy-en-Josas
}

On a sample of 4822 Large White and 2777 French Landrace pigs tested from 1970 to 1978 in six progeny-tesiing siations, the following variables were considered : growth traits over the $35-100 \mathrm{~kg}$ liveweight interval, i.e. individual average daily gain (ADG) and food conversion ratio (FCR) on a two-sib-pen basis, carcass (using the standardized Parisian jointing system) and meat quality traits after slaughter at $100 \mathrm{~kg}$ liveweight. Heritability estimates for ADG and FRC were close to those obtained over the same period on individuallyfed boars of the same breeds in the performance-testing stations (Ollivier et al., 1980, Techni-Porc, $3(1), 7-12)$. The highest heritabilities were obtained for the weights of loin $(0.60 \pm 0.06)$ and backfat $(0.61 \pm 0.06)$. Among the three meat quality traits considered ( $\mathrm{pH}$, colour, water-holding capacity), the most highly heritable was colour, measured by a reflectometer $(0.27 \pm 0.05)$. The dam components of varianca largely exceeded the sire components, especially for $\overline{A D G}$ (sib correlation 0.78 ) and meat quality (sib correlation 0.30 ). This may be 
considered, for ADG, as a consequence of group-feeding the two sibs in a common pen and, for meat quality traits, as an effect of the «common slaughter-day environment », as the two sibs were usually slaughtered on the same day. Phenotypic and genetic correlations between ADG and FCR were lower than the usual estimates under individual feeding. The genetic correlations between meat quality and the other traits were low, the highest one being obtained for FCR $(0.23 \pm 0.16)$.

\title{
A first evaluation of the Duroc breed
}

\author{
P. SELLIER \\ I.N.R.A., Station de Génétique quantitative et appliquée, \\ Centre de Recherches zootechniques, \\ F 78350 Jouy-en-Josas
}

The Duroc (D) breed was compared to the Piétrain (P), Belgian Landrace (B) and Hampshire $(\mathrm{H})$ breeds in terms of their respective merit as sire line of a 3 way-cross involving French Landrace $\times$ Large White dams. Fattening and carcass data were recorded on 573 pigs sired by a number of boars from the 4 breeds $(10 \mathrm{P}, 15 \mathrm{~B}, 13 \mathrm{H}$ and $11 \mathrm{D}$ boars) and fed ad libitum from 32 to $101 \mathrm{~kg}$ liveweight. Means of XP $(\mathrm{n}=141), X B(\mathrm{n}=144)$, $\mathrm{XH}(\mathrm{n}=140)$ and $\mathrm{XD}(\mathrm{n}=148)$, pigs respectively were (two means with the same superscript are not different at the 5 p. 100 level) : $728^{\mathrm{a}}, 792^{\mathrm{l}}, 845^{\prime}$ and $801^{\mathrm{l}}$ for average daily gain (g) ; $2.62^{\mathrm{a}}, 2.78^{\mathrm{b}}, 2.95^{\mathrm{c}}$ and $2.86^{\mathrm{l} c}$ for daily feed consumption $(\mathrm{kg}) ; 3.66^{\mathrm{a}}, 3.54^{\mathrm{a}}, 3.51^{\mathrm{a}}$ and

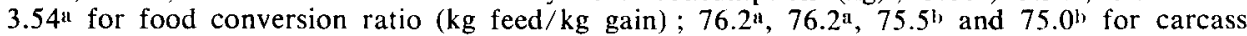
weight $(\mathrm{kg}) ; 94.7^{\mathrm{a}}, 98.2^{\mathrm{c}}, 96.3^{\mathrm{b}}$ and $96.9^{\mathrm{b}}$ for carcass length $(\mathrm{cm}) ; 24.5^{\mathrm{a}}, 24.7^{\mathrm{a}}, 25.0^{\mathrm{a}}$ and $24.4^{\mathrm{a}}$ for average backfat thickness $(\mathrm{mm}) ; 53.5^{\mathrm{a}}, 52.9^{\mathrm{ab}}, 52.5^{\mathrm{ab}}$ and $52.0^{\mathrm{b}}$ for estimated lean percentage. In ultimate $\mathrm{pH}$ and colour of meat, the $\mathrm{XH}$ type differed $(p<0.01)$ from the three other genetic types which gave similar results in this respect : meat from XH pigs exhibited a lower ultimate $\mathrm{pH}$ and a paler colour. The overall economic merit of the pigs from the four 3 way crosses was estimated, taking into account fattening cost and commercial value of the carcass : on this basis, the $\mathrm{XB}$ and $\mathrm{XH}$ types were similar and both were better than the $X D$ and, to a greater extent, $X P$ types. This first evaluation of the Duroc suggests that this breed has not to play a major part as a sire breed or as a component of a crossbred boar for terminal crossing, at least in the present conditions of pig production in France.

\section{Comparative study on the reproductive performance, fattening performance and carcass quality of Creole and Large White pigs in Guadeloupe}

\author{
I. CANOPE et Y. RAYNAUD \\ I.N.R.A., Station de Recherches zootechniques, \\ Antilles-Guyane, 97170 Petit-Bourg, Guadeloupe \\ Ingénieur Agronome de l'E.N.S.A., Toulouse \\ (Volontairc à l'Aide Technique en Guadeloupe), France
}

\begin{abstract}
Reproductive performance of a sample of Large White sows imported from France was compared to those of a local breed (Créoles).

Age and weight at puberty were 171.4 days and $52.3 \mathrm{~kg}$, respectively for the local breed and 275 days and $107 \mathrm{~kg}$ for the Large White pig, but no difference was observed between weaning-oestrus and weaning-successful mating.
\end{abstract}

